\title{
Patient safety education of the graduation in Nursing from the teaching perspective
}

\author{
Ensino sobre Segurança do Paciente em curso de graduação em Enfermagem na perspectiva docente \\ Enseña sobre Seguridad del Paciente en curso de graduación en Enfermería en la perspectiva docente
}

Elena Bohomol ${ }^{1}$

1. Universidade Federal de São Paulo. São Paulo, SP, Brasil.
Corresponding author:

Elena Bohomol.

E-mail: ebohomol@unifesp.br.

Submitted on $12 / 02 / 2018$.

Accepted on 01/18/2019.

DOI: 10.1590/2177-9465-EAN-2018-0364

\section{Abstract}

Objective: to identify contents related to Patient Safety contemplated in the curricular units of a Nursing undergraduate course according to the teachers who work in it, and to know the teaching methodologies and evaluation strategies used. Method: descriptive case study, carried out with 15 professors of the Nursing undergraduate course of a Brazilian public institution, in 2014 , who answered an online questionnaire. For data analysis, the guide of the World Health Organization was used as reference. Results: it was verified that patient safety contents are developed in the undergraduate course, referring to eight topics mentioned in the World Health Organization guide. There was a lack of contents of the topics "What is Patient Safety", "Why applying human factors is important for Patient Safety"; and "Learning from errors to prevent harm". The use of different teaching methodologies and evaluation strategies, both traditional and innovative, was identified. Conclusion and implications for the practice: the pedagogical project of the course must be revised, to align content, teaching methodologies and evaluation strategies and to promote the full development of this subject, both in the undergraduate Nursing course and in the other courses of the Health area.

Keywords: Patient Safety; Universities; Education, Nursing, Diploma Programs; Education, Nursing; Faculty, Nursing.

\section{RESUMO}

Objetivo: identificar os conteúdos relacionados à Segurança do Paciente contemplados nas unidades curriculares de um curso de graduação em Enfermagem, segundo docentes que nele atuam e conhecer as metodologias de ensino e avaliação utilizadas. Método: estudo de caso descritivo, realizado com 15 docentes do curso de graduação em Enfermagem de uma instituição pública brasileira, em 2014, que responderam a um questionário online. Para a análise dos dados, tomou-se como referência o guia da Organização Mundial da Saúde. Resultados: verificou-se que os conteúdos sobre Segurança do Paciente são desenvolvidos no curso de graduação, referentes a oito tópicos citados no guia. Observou-se a falta de conteúdos relacionados aos tópicos "O que é a Segurança do Paciente", "Por que empregar fatores humanos é importante para a Segurança do Paciente" e "Aprender com os erros para evitar danos". Foi identificada a utilização de diversas metodologias de ensino e estratégias de avaliação, tanto tradicionais quanto inovadoras. Conclusão e implicações para a prática: faz-se necessária a revisão do projeto pedagógico do curso para alinhar conteúdos, metodologias de ensino e estratégias de avaliação e favorecer o desenvolvimento pleno dessa temática, tanto no curso de graduação em Enfermagem quanto nos demais cursos da área da Saúde.

Palavras-chave: Segurança do Paciente; Universidades; Programas de Graduação em Enfermagem; Educação em Enfermagem; Docentes de Enfermagem.

\section{REsumen}

Objetivo: identificar los contenidos relacionados a la Seguridad del Paciente contemplados en las unidades curriculares de un curso de graduación en Enfermería, según docentes que en él actúan y conocer las metodologías de enseñanza y las estrategias de evaluación utilizadas. Método: estudio de caso descriptivo, realizado con 15 docentes del curso de graduación en Enfermería de una institución pública brasileña, en 2014, que respondieron a un cuestionario en línea. Para el análisis de los datos, se tomó como referencia la guía de la Organización Mundial de la Salud. Resultados: se verificó que contenidos sobre la Seguridad del Paciente se desarrollan en el curso de graduación, referentes a ocho tópicos citados en la guía de la Organización Mundia de la Salud. Se observó la falta de contenidos de los tópicos "Qué es la Seguridad del Paciente", "Por qué emplear factores humanos es importante para la Seguridad del Paciente" y "Aprender con los errores para evitar daños". Se identificó la utilización de diversas metodologías de enseñanza y estrategias de evaluación, tanto tradicionales como innovadoras. Conclusión e implicaciones para la práctica: se hace necesaria la revisión del proyecto pedagógico del curso, para alinear contenidos, metodologías de enseñanza y estrategias de evaluación y favorecer el desarrollo pleno de esta temática, tanto en el curso de graduación en Enfermería como en los demás cursos de la enseñanza del área de la Salud.

Palabras clave: Seguridad del Paciente; Universidades; Programas de Graduación en Enfermería; Educación de Enfermería; Docentes de Enfermería. 


\section{INTRODUCTION}

According to the World Health Organization (WHO), Patient Safety is the absence of unnecessary harm or potential harm associated with health care. ${ }^{1}$ The estimates of preventable errors and adverse events are alarming, this is why actions that should be implemented to improve care must be discussed., ${ }^{2,3}$ Among them, is the training process of professionals of which educational institutions are part. ${ }^{4}$

Student training involves a complex system with numerous variables that encompass different teaching practices, diversity of content, permanent reflection on information of reality and problematization of the working method, surpassing structural resources available in each institution. ${ }^{4}$

Training organizations have long been drawn to the need for reassessing curricula, incorporating the concepts of Patient Safety and the development of specific skills, aiming at the education of undergraduates with opportunities for the development of interdisciplinary practice. ${ }^{3,5}$

In this context, the WHO launched the multiprofessional education program in 2011 , focusing on the education of future dentists, physicians, midwives, nurses, pharmacists and other professionals who provide aid to patients, assisting managers, teachers and tutors to address this issue in daily life. ${ }^{6}$

The Ministry of Health (MS) from Brazil presented the National Patient Safety Program (Programa Nacional de Segurança do Paciente-PNSP) in 2011. Promoting the inclusion of the topic Patient Safety in technical, undergraduate and post-graduation courses in the Health area was among the objectives. ${ }^{7}$

Training professionals for the 21 st century should be directed to meet the principles of transformative and interprofessional education and demand the transformation of the Pedagogical Projects (PP) in schools. ${ }^{8}$

As for teaching Patient Safety in Brazil, Nursing stands out in this discussion, since it represents the largest health workforce, deals directly with patients and their families and must be prepared to respond to the needs of the healthcare system. ${ }^{8}$ Its contributions range from research, proposals for to improve organizations to protagonism on the discussion around the needs for change in training professionals..$^{8-9}$

The Brazilian Network of Nursing and Patient Safety (Rede Brasileira de Enfermagem e Segurança do Paciente - REBRAENSP), founded in 2008 and linked to the Pan American Health Organization and the WHO, spreads the Patient Safety culture in health and education institutions through the work of its poles and nuclei, thus fomenting the discussion about the need to build safe and quality care. ${ }^{10}$

Considering it is a new subject in the curricula, studies have been carried out in the curricular matrices of undergraduate courses in the Health area, as well as in Nursing, to know what is taught about Patient Safety and promote reflection on curricular changes. ${ }^{11,12}$ These are important types of studies which are in accordance with the WHO guidelines, since they guide that schools should first analyze the existing curriculum and determine which points are already taught through a mapping, to identify opportunities for including new principles and concepts. ${ }^{6}$

The guide does not say there should be an isolated discipline on Patient Safety in the PP but emphasizes the importance of integration between the various areas of knowledge and health care lines. In addition, it addresses a variety of teaching methods that can be used to introduce Patient Safety topics, as well as assessment strategies in a variety of formats to support educational goals at the end of learning. ${ }^{6}$

In order to comply with Resolution No. 569/2017, schools should consider this issue in their PP, committing to the PNSP in the search for the best scientific evidence to reduce diseases and iatrogenies. ${ }^{13}$ As a contribution to this field, this study aims to identify contents related to Patient Safety contemplated in the Curricular Units (CU) of Nursing undergraduate courses, according to the professors who work in a Brazilian public institution, besides acknowledging the teaching methodologies and evaluation strategies used.

\section{METHOD}

A descriptive case study with a qualitative approach, given it focuses on the identification of a contemporary, difficult quantification event that is teaching about Patient Safety. ${ }^{14}$ The study was carried out in the undergraduate Nursing course of a federal public institution, founded in the metropolitan region of São Paulo in 1939, which seeks to train generalist nurses with competencies to act in the biopsychosocial dimensions that involve the health process, illness and care of individuals, families and community, based on the principles of the Unified Health System. Its workload is of 4,652 hours, full time, duration of four years and structured in three areas of knowledge: Biological and Health Sciences, Human and Social Sciences, and Nursing Science. The course is based on the National Curriculum Guidelines from 2001 and promoted the change of curriculum in 2010, having implemented the new PP in 2012, current until the data collection. ${ }^{15}$

The PP is structured in a traditional way, and students first learn Biological and Health Sciences (basic) and Humanities and Social Sciences, and only then focus on specific areas needed for the practice of the profession related to the Nursing Science. Its approach is not integrated between CUs, axis or departments.

The population was constituted by the professors responsible for the undergraduate Nursing course CU, whose identification was confirmed by the academic secretary of the course. The compulsory modalities that make up the PP with contents and duration endorsed by the Course Commission and the Undergraduation Council of the University are called CU. They are presented under the discipline category (contemplates theoretical or practical-theoretical activities) or internship (contemplating eminently practical activities)

The inclusion criteria for participants was the identification of their CU in a documentary study, ${ }^{16}$ occasion in which the PPs of Nursing, Pharmacy, Physiotherapy and Medicine courses of the same university were analyzed. Twenty-five teachers were invited, first personally and then, officially, through an electronic invitation, with a link to Google Docs. In case of acceptance, the 
Free and Informed Consent Form was presented, and only after the agreement was confirmed in the system, the three screens related to research were made available. Each screen contained three parts: the question, the text and a field for the answer. The first screen consisted of the question "What content about Patient Safety do you teach?", followed by the text with the presentation of topics from the guide and possible contents to be taught, according to the terms-trackers based on the WHO guide topics.

The second screen presented the question "Which teaching methodology (s) do you use?" and a list of teaching methodologies from the WHO guide. On the third screen, the question was "Which evaluation strategy(ies) do you use?" and a list of evaluation strategies also extracted from the same guide.

The answers to the questions were written by the participants in the open field, without limitation of space, so that they could ponder, elaborate and revise their own texts. Information was sent electronically from the Google Docs form and only accessed by the researcher by opening the screen "display summary of responses".

Fifteen teachers participated, who answered an online questionnaire. Participants who did not submit their answers after three biweekly reminders were excluded. Data were collected from July to October 2014.

For the analysis of data, reference was made to the WHO guide, which establishes guidelines for teaching Patient Safety regarding content, methodology and evaluation. The WHO guide is considered an effective document to integrate and strengthen academic and professional education on Patient Safety and quality of health care, providing requirements and tools that should be incorporated into education. ${ }^{17-18}$

The data were operationalized by reading the answers and the Excel ${ }^{\circledR}$ worksheet was used for organization. A classification analysis was made, that is, from the identification of the participants' response, it was put into one of the topics of the WHO guide, in relation to its contents, formats and strategies of teaching and evaluation suggested in each one. The interpretation regarding these findings was made from this classification.

The study was approved by the Ethics and Research Committee of the Federal University of São Paulo, opinion No. 9852 from April $25^{\text {th }}, 2012$, respecting the ethical precepts set forth in Resolution $466 / 2012$ by the National Health Council.

\section{RESULTS}

The fifteen teachers who participated in the study were responsible for the CUs of Fundamentals, Methods and Techniques of Teaching and Epidemiology, taught in the first period; General Administration and Economics, Management of Health and Nursing Services (Gerenciamento de Serviços de Saúde e Enfermagem - GSSE) I, Mental Health in Nursing and Clinical Nursing, taught in the second period; Health Information and Communication Technologies and Systems, Health Care Integrality, GSSE II, Nursing in the Promotion of Child and Adolescent Health, Legislation and Ethics; Nursing in Clinical and Surgical Pediatrics, Nursing in Neonatal Health, taught in the third period; and Emergency Nursing and GSSE III, taught in the fourth period of the course.

Table 1 presents the eight topics of the WHO guide and their distribution between periods and CUs indicated by the professors of the Nursing undergraduate course.

The contents were diverse and distributed in a heterogeneous way, sometimes repeated, in the curricular program. In the topic "Understanding systems and the effect of complexity on patient care", those contents that address organizational structure, health system, work processes, interdisciplinarity and defenses and barriers in the systems are highlighted, starting from the second period of the course.

The topic "Being an effective team player" is addressed throughout student training, with content related to what is a team, different types of teams found in health care, team coordination, teamwork performance evaluation, effective leadership and conflict resolution.

The topic "Understanding and managing clinical risk" addresses issues related to the organization and work environment, communication and poor communication and stress, highlighted in the second period of the course and in a CU.

The topic "Using quality improvement methods to improve care" addresses the use of indicators, processes for improving clinical practice, the improvement of processes and use of quality tools, and takes place throughout the entire curricular program.

The topic "Engaging with patients and carers" includes content related to user rights, informed consent, patient privacy and autonomy, respect for differences among patients, legal implications of errors, ways of involving patients and professionals in health decisions, and are taught in the first three periods of the course.

Likewise, the topic "Infection prevention and control" addresses the issues of health-care -related infections in multiples care scenarios, including aspects related to community infections, antimicrobial resistance, use of personal and collective protective equipment, immunizations, presentation of updated guidelines on the topic.

The topic "Patient Safety and invasive procedures" addresses issues related to surgical Patient Safety, adverse events related to surgical procedures and other invasive procedures, surgical site complications, and operative patient management.

The topic "Improving medication safety" presents content related to the medication system and prescription process, distribution and administration, access of users to medications, side effects, adverse drug reaction, medication errors and their types, medication combination, high-alert medications and decision-support systems, taught in the second and third periods of the course.

Of the total WHO guideline topics, three had no identified content, namely: "What is Patient Safety", "Why employing human factors is important for Patient Safety" and "Learning from errors to prevent harm" evidencing gaps in the PP.

Regarding teaching and evaluation methodologies, teachers reported different formats. For the topic "Understanding systems 
of cases and clinical supervision. It was also verified the use of problem-based learning, a methodology that emphasizes the development of critical thinking skills and problem solving in students. The professors indicated the use of technological resources to aid in teaching, such as systems and applications or distance learning.

Participants also reported using more traditional assessments, such as formal evaluation, oral assessment or a more innovative approach, such as participation in a mock jury court or chats, forums and tasks in distance learning. In addition to evaluations that focus on the theoretical aspect, some strategies were considered for the evaluation of the practical part, such as presentation of a clinical case study, direct observation of the context of the actual or simulated practice and self-assessment. Other strategies used for evaluation are also related to teaching, such as the portfolio.

\section{DISCUSSION}

Research allowed to improve the knowledge of how to teach Patient Safety in a Nursing undergraduate course of a public university, as well as to identify teaching and evaluation strategies, promoting a better knowledge regarding the training process using information shared by the professors.

A large part of contents is taught by professionals, and similar data were found in a documentary study that analyzed the curricula of Nursing schools in the city of São Paulo. ${ }^{12}$

Despite existing information on the subject, there was no discussion to change the PP regarding Patient Safety in the school researched. However, it is understood that this is a fundamental step to comply with Resolution 569/2017, which reinforces that the knowledge and practices nuclei consider this theme in their program. ${ }^{13} \mathrm{~A}$ study demonstrated the heterogeneity of the PP of undergraduate courses in Nursing, be it in Brazil or in other Latin American countries and in the Caribbean, and presented a number of recommendations, including periodic review of curricula and development of monitoring quality assessment, evaluation reporting and improvement plans as recommended by the WHO. ${ }^{8}$

Such information corroborates a study that evaluated the implementation of safety themes in health courses in low and middle-income countries, revealing that most of them (69\%) were considering the possibility of implementing a new curriculum based on the WHO guide on teaching Patient Safety. Nonetheless, even acknowledging the need to improve students' training in this area, barriers to curricular change were pointed out, such as lack of government commitment, lack of financial resources, lack of definition of evaluation tools, lack of leadership with knowledge and ability to do so and insufficient information to enable the faculty to participate in its construction. ${ }^{18}$

The study presents the WHO Guide as an important reference for curricular changes concerning the implementation of Patient Safety content, proving to be culturally appropriate for different countries in different continents. ${ }^{17}$

Notably, research presents the engagement of the professors of several CUs in the development of Patient Safety contents.
However, there is no clear recognition of the integration between them in the ways of teaching or evaluating. Teaching Patient Safety is not explicit in the PP. ${ }^{15}$

The incorporation of Patient Safety into Nursing undergraduate training still faces many challenges worldwide and, therefore, there is a need for a close look at this issue. Within an educational institution, there is a need for consensus on the elements that should be addressed, which methodologies should be adopted for content development, which competences will be developed in students, allowing to combine the theoretical and practical aspects of training. ${ }^{19}$ The need to develop and integrate Patient Safety into the curriculum in a challenging learning environment is reinforced, and for this, preparing professors and making resources available are needed for teaching to be promoted in all contexts. ${ }^{6}$

In this study, educational gaps have been found. They impede a global view on Patient Safety and some examples are: the culture of guilt, safety models, adverse events, human and economic costs, work environment, patient care ergonomics, fatigue and performance stress, learning from mistakes, reporting errors that pertain to the topics "What is Patient Safety", "Why employing human factors is important for Patient Safety" and "Learning from errors to prevent harm". A study carried out with students of two Nursing undergraduate courses pointed to the weaknesses in teaching certain contents and emphasized the importance of addressing topics, such as the culture of guilt, to prevent the continuity of the culture of punishment and to enable the understanding of error as an opportunity for learning, encouraging reflections to improve the Nursing work processes. ${ }^{11}$

International research pointed to these items as quite difficult to implement in a health curriculum and added the topic "Being an effective team player", as one of the most complex ones, unlike the finding in this study. ${ }^{18}$

The results indicated students' development of knowledge regarding "Infection prevention and control", "Patient Safety and invasive procedures" and "Improving medication safety", showing alignment with the global challenges proposed by the $\mathrm{WHO}$ and PNSP. ${ }^{6-7}$ In a documentary study on the PP of Nursing courses, the authors pointed out the importance of these topics, referring to them as frequent in the programmatic contents and highlighting their need to be articulated throughout the course and with other disciplines that make up the PP. ${ }^{12}$

The results revealed that Patient Safety content has been addressed since the first period of the course, and students have contact with them throughout their entire training. Studies emphasize the importance of training nurses competent at Patient Safety, stressing the need for these aspects to be taught from the beginning of the course and seen as a continuous procedure throughout the training process. In this way, there is a better development of knowledge, attitudes, values, skills and practices that make future professionals aware of promoting and improving the patient's safe care..$^{19-20}$

Research identified the use of different teaching methodologies, including several within the same CU. The coexistence of 
traditional and innovative methodologies was clear, and there is no clear orientation of theoretical-methodological references that lead the teaching activity. One study demonstrated the need to change the traditional vision of the teaching/learning process focused on Patient Safety by implementing active, more favorable and effective methodologies to train professionals. ${ }^{9}$ This affirmative corroborates with another study on the education in Nursing that recommends the use, by the faculty, of strategies to promote active learning. ${ }^{8}$

In relation to teaching about Patient Safety, the WHO instructs professors to adopt strategies that they believe work well and make them comfortable. The goal is for them to develop skills to create engaging learning activities, taking into account the time and resources available. ${ }^{6,21}$ These recommendations meet the need for changes in teaching, by adopting new cognitive practices permeated by multiple individual intelligences and in an integrated way. ${ }^{4,22}$

The evaluation is an integral part of any curriculum and, in the present study, there was a diversity of strategies used. Many of these are related to a more traditional approach, which aims to verify the reproduction of the contents communicated in the classroom to evidence how much information has been apprehended. ${ }^{23}$

The study also showed that strategies are adopted with more innovative approaches, in which the evaluation consists of verifying that students learned, reaching the objectives proposed by the CU. This type of assessment is seen as an integral part of the conditions for the occurrence of learning and is related to knowing if the desired final behaviors were acquired. ${ }^{4,6}$

The evaluative process is important, given Patient Safety should not be a punctual aspect within the health curriculum. It has repercussions on care practices throughout the professional life. ${ }^{23}$ The evaluation of being competent in Patient Safety is as complex as or even more complex than those occurring during courses in the Health area. It is not only a matter of saying that students performed a given activity, but that there is continuous development of knowledge and skills in this aspect. Because Patient Safety depends on a complex set of factors and people, one of the major challenges facing education is finding instructors or health professionals who are well suited to teach Patient Safety in the practice environment. ${ }^{4,9}$

\section{CONCLUSION AND IMPLICATIONS FOR PRACTICE}

An expressive number of Patient Safety contents developed throughout the curricular program of the undergraduate Nursing course based on the World Health Organization guide was identified. Topics are not taught as an autonomous course but are incorporated into several different curricular units.

Research showed that professors are involved in the subject. Nonetheless, there is no integration between curricular units and periods to establish a consensus on the elements that must be addressed, in addition to the alignment and development of content with appropriate methodologies.

Nursing students have been engaged with Patient Safety since the first period of the course, which can have a significant impact on the development and shaping of their knowledge, skills, and behaviors for safe care.

It was observed that several teaching methodologies, both traditional and innovative, are used. Although it is recommended to use different strategies, those related to active methodologies should be incorporated into the teaching of Patient Safety.

The evaluation strategies mentioned also reflect the coexistence of traditional and innovative aspects. The evaluation focused on Patient Safety should not be a specific aspect of the health curriculum, because it has repercussions on the care practices throughout the lives of future professionals.

This study contributes to undergraduate education, considering the worldwide movement for curricular adequacy. An assessment the pedagogical project of the school is important to align the topics pointed out by the guide of the World Health Organization, to discuss teaching methodologies and evaluation strategies and enable the full development of this subject in the Nursing course and in other courses of the Health area.

As research limitation, the participants which represented the study population were identified from the data of a documentary study previously performed in the Nursing course pedagogical project, and losses may have occurred in the sample portrayed.

New studies on teaching Patient Safety in undergraduate Nursing courses are suggested, using other research methods that encourage the participation of professors and students, thus making it possible to evaluate the changes implemented in the pedagogical projects of the courses and their impacts on health care.

\section{REFERENCES}

1. World Health Organization (WHO). Conceptual Framework for the International Classification for Patient Safety. Version 1.1. Final Technical Report January 2009 [Internet]. Geneva: World Health Organization; 2009 Jan [cited 2018 Jun 12]. Available from: http://apps. who.int/iris/bitstream/handle/10665/70882/WHO_IER_PSP_2010.2_ eng.pdf? sequence $=1$ \&isAllowed $=y$

2. Hutton B, Kanji S, McDonald E, Yazdi F, Wolfe D, Thavorn K, et al. Incidence, causes, and consequences of preventable adverse drug events: protocol for an overview of reviews. Syst Rev [Internet]. 2016 Dec; [cited 2018 Jun 12]; 5:209. Available from: https://www.ncbi.nlm. nih.gov/pmc/articles/PMC5139092/.DOI: 10.1186/s13643-016-0392-4

3. Kohn LT, Corrigan JM, Donaldson MS. To Err is Human: Building a Safer Health System. Washington (DC): National Academy Press 2000 [cited 2018 Jun 20]. Available from: https://www.ncbi.nlm.nih. gov/books/NBK225182/

4. Freitas DA, Santos EMS, Lima LVS, Miranda LN, Vasconcelos EL, Nagliate PC. Teachers' knowledge about teaching-learning process and its importance for professional education in health. Interface (Botucatu). [Internet]. 2016 Jun; [cited 2018 Jun 20] ;20(57):437-48. Available from: http://www.scielo.br/scielo.php?script=sci_arttext\&pid=S141432832016000200437\&lng=en. DOI: http://dx.doi.org/10.1590/180757622014.1177 
5. Institute of Medicine (US) Committee on Quality of Health Care in America. Crossing the Quality Chasm: A New Health System for the 21st Century. Washington (DC): National Academies Press (US); 2001 [cited 2018 Jun 1]. Available from: https://www.ncbi.nlm.nih.gov/ pubmed/25057539

6. World Health Organization (WHO). Patient Safety Curriculum Guide Multi-professional Edition [Internet]. Geneva: World Health Organization; 2011 [cited 2018 Jun 20]. 271 p. Available from: http://apps. who.int/iris/ bitstream/handle/10665/44641/9789241501958_eng.pdf?sequence=1

7. Ministério da Saúde (BR). Portaria MS/GM No. 529, 1 de abril de 2013. Institui o Programa Nacional de Segurança do Paciente (PNSP). Brasília (DF): Diário Oficial da União; 2013. [Internet]. 2013 [cited 2015 Aug 14]. Available from: file:///C:/Users/susana/Downloads/portaria\%20ms\%20 n\%20529\%202013\%20-\%20segurana\%20do\%20paciente.pdf

8. Cassiani SHDB, Wilson LL, Mikael SSE, Morán Peña L, Zarate Grajales R, McCreary LL, et al. The situation of nursing education in Latin America and the Caribbean towards universal health. Rev Lat Am Enferm [Internet]. 2017 May; [cited 2018 Aug 27]; 25:e2913. Available from: http://www.scielo.br/scielo.php?script=sci arttext\&pid=S0104-11692017000100331\&lng=en\&tIng=en. DOI: $\mathrm{http}: / /$ dx.doi.org/10.1590/1518-8345.2232.2913

9. Wegner W, Silva SC, Kantorski KJC, Predebon CM, Sanches MO, Pedro ENR. Education for culture of patient safety: Implications to professional training. Esc Anna Nery [Internet]. 2016 Jun; [cited 2018 Aug 27]; 20(3):e20160068. Available from: http://www.scielo.br/scielo. php?script=sci_arttext\&pid=S1414-81452016000300212\&Ing=en http://dx.doi.org/10.5935/1414-8145.20160068.

10. Caldana G, Guirardello EB, Urbanetto JS, Peterlini MAS, Gabriel CS. Brazilian network for nursing and patient safety: challenges and perspectives. Text Context Nurs [Internet]. $2015 \mathrm{Jul} / \mathrm{Sep}$; [cited 2018 Aug 27]; 24(3):906-11. Available from: http://www.scielo.br/ pdf/tce/v24n3/0104-0707-tce-24-03-00906.pdf. DOI: http://dx.doi. org/10.1590/0104-070720150001980014

11. Bim LL, Bim FL, Silva AMB, Sousa AFL, Hermann RS, Andrade D, et al. Theoretical-practical acquisition of topics relevant to patient safety: dilemmas in the training of nurses. Esc Anna Nery [Internet]. 2017 Aug; [cited 2018 Aug 27]; 21(4):e20170127. Available from: http://www.scielo.br/scielo.php?script=sci arttext\&pid=S141481452017000400206\&lng=en. DOI: http://dx.doi.org/10.1590/21779465-ean-2017-0127

12. Melleiro MM, Tronchin DMR, Lima MOP, Garzin ACA, Martins MS, Cavalcante MBG, et al. Thematic patient safety in the curricular matrices of undergraduate schools in nursing and obstetric. Rev Baiana Enferm [Internet]. 2017; [cited 2018 Jun 20]; 31(2):e16814. Available from: file:///C:/Users/susana/Downloads/16814-77563-2-PB.pdf. DOI: 10.18471/rbe.v31i2.16814

13. Ministério da Saúde (BR). Resolução № 569 de 8 de dezembro De 2017. Brasília (DF): Diário Oficial da União ; 2017. [cited 2018 Aug 28]. Available from: http://conselho.saude.gov.br/resolucoes/2017/Reso569. pdf
14. Yin RK. Case Study: Planning and Methods. Porto Alegre: Bookman; 2015.

15. Universidade Federal de São Paulo, Campus São Paulo. Pedagogical Project for Nursing graduate program: update of pedagogical project 2012. São Paulo: Universidade Federal de São Paulo; 2012.

16. Bohomol E, Freitas MAO, Cunha ICKO. Patient safety teaching in undergraduate health programs: reflections on knowledge and practice. Interface (Botucatu) [Internet]. $2016 \mathrm{Jul} / \mathrm{Sep}$; [cited 2018 Jun 19]; 20(58):727-41. Available from: http://www.scielo.br/scielo. php?script=sci_arttext\&pid=S1414-32832016000300727\&lng=en. DOI: http://dx.doi.org/10.1590/1807-57622015.0699.

17. Farley D, Zheng H, Rousi E, Leotsakos A. Field Test of the World Health Organization Multi-Professional Patient Safety Curriculum Guide. PLoS One [Internet]. 2015; [cited 2019 Jan 10]; 10(9):e0138510. Available from: https://www.ncbi.nlm.nih.gov/pmc/articles/PMC4583458/. DOI: 10.1371/journal.pone.0138510

18. Ginsburg LR, Dhingra-Kumar N, Donaldson LJ. What stage are lowincome and middle-income countries (LMICs) at with patient safety curriculum implementation and what are the barriers to implementation? A two-stage cross-sectional study. BMJ Open [Internet]. $2017 \mathrm{Jun}$; [cited 2018 Oct 6]; 7(6):e016110. Available from: https://www.ncbi.nlm.nih.gov/ pubmed/28619782. DOI: 10.1136/bmjopen-2017-016110

19. Mansour MJ, Shadafan SF, Abu-Sneineh FT, AIAmer MA. Integrating Patient Safety Education in the Undergraduate Nursing Curriculum: A Discussion Paper. Open Nurs J [Internet]. 2018; [cited 2018 Oct 7] 12:125-32. Available from: https://www.ncbi.nlm.nih.gov/pmc/articles/ PMC6040211/.DOI: 10.2174/1874434601812010125

20. Olaf T, De Vos M, Eric F. The effectiveness of a course on patient safety management on the patient safety competencies by final year bachelor of nursing students in the Netherlands. Health Edu Care [Internet].2017 [cited 2018 Oct 6]; 2(4):1-5. Available from: https://www.oatext.com/pdf/ HEC-2-128.pdf. DOI: 10.15761/HEC.1000128

21. Domingues NA, Ohnuma CS, Tsuda M, Lotufo ML, Valério Neto L, Santos WF, et al. Educational game about Patient Safety: evaluation of Nursing students. Nuevas Ideas Inform Educativa TISE [Internet]. 2015; [cited 2018 Jun 20]; 11:684-8. Available from: http://www.tise.cl/volumen11/ TISE2015/684-688.pdf

22. Baker VOT, Cuzzola R, Knox C, Liotta C, Cornfield CS, Tarkowski RD et al. Teamwork education improves trauma team performance in undergraduate health professional students. J Educ Eval Health Prof [Internet]. 2015; [cited 2018 Jun 12]; 12:36. Available from: https:// www.ncbi.nlm.nih.gov/pmc/articles/PMC4536358/. DOI: 10.3352/ jeehp.2015.12.36

23. Cavalcante LPF, Mello MA. Avaliação da aprendizagem no ensino de graduação em saúde: concepções, intencionalidades, reflexões. Avaliação (Campinas/ Sorocaba) [Internet]. 2015 Jul; [cited 2018 Jun 12]; 20(2):423-42. Available from: http://www.scielo.br/pdf/aval/ v20n2/1414-4077-aval-20-02-00423.pdf. DOl: http://dx.doi.org/10.590/ S1414-40772015000200008 